\title{
Minissaias, militâncias, revoluções e gênero na última ditadura argentina*
}

\author{
Ana Maria Veiga**
}

O livro De minifaldas, militancias y revoluciones: exploraciones sobre los 70 en la Argentina amplia o debate sobre a última ditadura militar naquele país (1976-1983) ao inserir nele questões de gênero $e$ a participação política das mulheres nos grupos de resistência.. Organizado por Andrea Andújar, Karin Grammático, Débora D’Antonio, Fernanda Gil Lozano e María Laura Rosa, o livro dá sequência à compilação eletrônica Historia, Género y Política en los '70 (Andújar, 2005), editada online pelo mesmo grupo no ano de 2005, como resultado das jornadas ocorridas na Universidade de Buenos Aires ${ }^{1}$, que lembraram os trinta anos do começo da ditadura argentina, abordando especificamente as relações de gênero.

A primeira parte da obra, denominada "Espacios de Militancia y Conflictividad", é composta de quatro capítulos. Marta Vassalo aborda a situação das mulheres nas fileiras militantes, tratadas como duplamente subversivas, já que fugiam aos seus papéis tradicionais, assumindo lugares considerados masculinos. Além disso, Vassalo explora a maternidade e as normas morais $e$ sexuais para os casais militantes, que tinham seus relacionamentos mediados pelos ditames das organizações - a descoberta do

\footnotetext{
"Resenha de ANDÚJAR, Andrea et alii. De minifaldas, militancias y revoluciones: exploraciones sobre los 70 en la Argentina. Buenos Aires, Ediciones Luxemburg, 2009, 217 p. Recebida para publicação em agosto de 2010, aceita em março de 2011.

** Doutoranda em História na Universidade Federal de Santa Catarina e bolsista da CAPES. Atualmente pesquisa sobre realizadoras de cinema do Brasil e da Argentina durante as ditaduras militares nos dois países. amveiga@yahoo.com.br

${ }^{1}$ Em 2010 as jornadas alcançaram sua terceira edição.
} 
Minissaias, militâncias, revoluções e gênero...

feminismo e sua reivindicação vieram a complicar ainda mais a situação de algumas mulheres que passaram a atuar na chamada dupla militância. Em outro capítulo, Karin Grammático fala das disputas internas do Movimento Peronista e das manobras e demandas da "Rama Femenina", que tomou lugar nesse movimento. A autora aponta para as mulheres como grupo de interesse do peronismo, mas do qual não se fazia uma leitura política aprofundada; as mulheres teriam direitos políticos, dentro dos limites de seus papéis de mães e esposas, como as situava também Evita Perón. Além disso, Grammático faz uma interessante reflexão sobre a preocupação geracional do líder Perón, mesmo no exílio, de formar novos dirigentes a partir da Juventude Peronista. Segundo ela, Perón tentava apaziguar as agrupações armadas do movimento, como as Forças Armadas Peronistas e os Montoneros.

As trajetórias de religiosas "terceiromundistas" na Argentina são analisadas por Claudia Touris, que aponta os grupos de formação católica na renovação da esquerda nos anos 1960 e a ação limitada das mulheres dentro desses grupos, apesar da transformação das vidas das religiosas depois do Concílio Vaticano II; a aproximação com o peronismo e uma nova postura política marcaram a "nova mulher cristã", politicamente ativa. Luciana Seminara e Cristina Viano também seguem as trajetórias de duas mulheres que começaram a vida política em grupos católicos alinhados com a Teologia da Libertação e que acabaram por encontrar a luta armada praticada pelos Montoneros e pelo Partido Revolucionário de los Trabajadores, deparando-se ainda com o feminismo, em um momento de "direitização" do governo peronista, de repressão intensa e clandestinidade.

A segunda parte do livro, "Prácticas Terroristas, Prácticas de Resistencia”, é aberta com o capítulo de Débora D’Antonio, que aborda a agência política praticada dentro dos cárceres entre 1974 e 1983. A autora tematiza a resistência e a reorganização política das mulheres no cárcere de Villa Devoto, criando uma cultura política carcerária; além disso, trata de violência sexual, tortura, 
sujeição dos corpos e colaboração, discutindo as estratégias de sobrevivência dessas mulheres. O capítulo de Laura Rodriguez Agüero mostra a repressão sobre prostitutas e militantes de esquerda em Mendoza, de 1974 a 1976, período em que estiveram em atividade na região os conservadores Comando Anticomunista de Mendoza e o Comando Moralizador Pio XII, que ameaçavam, assassinavam, colocavam bombas em casas noturnas, casas de militantes de esquerda, centros israelitas e igrejas evangélicas. Pessoas mortas eram encontradas nuas, algumas com as cabeças raspadas; a morte era decretada a quem colocasse em questão modos de vida tradicionais: prostitutas, homossexuais, traficantes.

No capítulo que encerra esta parte, Marina Franco aponta o exílio como espaço de transformação de gênero. Desde 1973, com a repressão da Aliança Anticomunista Argentina, aproximadamente 300 mil foragidos deixaram o país. A autora analisa o papel ativo das mulheres diante da experiência migratória, a construção de novas percepções como força, segurança $e$ independência, e o encontro de muitas delas com o movimento feminista na França, para onde partiram quase dois mil e quinhentos argentinos/as. Mas a autora avisa que essa relação deve ser matizada, pois seus efeitos concretos foram limitados. A manutenção dos papéis periféricos das mulheres no exílio, com a reestruturação das organizações e o encontro com ideais liberalizantes, levou à ruptura de diversos casais, já que as mulheres adquiriram novas posições domésticas e políticas; portanto o exílio pode ter tido um efeito acelerador, como explica a autora, com o deslocamento de prioridades e a descoberta de novas demandas assumidas pelas mulheres.

A terceira parte do livro, "Representaciones, Imágenes y Vida Cotidiana", traz para o cenário historiográfico outras perspectivas, ainda incomuns nos meios acadêmicos. Andrea Andújar explora os vínculos de casal na militância política de esquerda dos anos 1970, trabalhando sobre a penetração mútua entre seus ideais e a cultura de massa, representada no capítulo pelas telenovelas e pelo rock and roll. Em um texto estimulante, 
Minissaias, militâncias, revoluções e gênero...

Andújar reflete sobre a constituição de novas formas de ser e se relacionar para as mulheres, com a erosão do mundo tradicional e o questionamento das relações heterossexuais, monogâmicas, visando o casamento. Enquanto o rock trazia o rechaço aos cânones sociais vigentes e a apologia ao amor livre (ainda heterossexual), colocando as mulheres como agentes que também tomavam iniciativas, as telenovelas as representavam em sua passividade, mas já traziam algumas inovações nos papéis; ambos os segmentos culturais traziam o contexto social e político dos primeiros anos 1970. Enquanto isso, as organizações de esquerda viam as inquietudes amorosas como debilidade política, naturalizavam as tarefas tidas como femininas e reproduziam o modelo de conduta pregado pela ditadura: amor duradouro, fidelidade, reprovação do adultério, concepção tradicional de família. A autora sinaliza a cultura como espaço de disputas e a tentativa de novos vínculos amorosos em ambiguidade com o imaginário tradicional sobre o amor e as relações.

Isabella Cosse também traz os novos protótipos femininos que emergiram naqueles anos com a divulgação da imagem da "jovem liberada", com desejo sexual ativo, que trabalhava e não tinha como meta o casamento; surgia uma nova sensibilidade moral, principalmente entre a classe média mais elevada, identificada com os Estados Unidos e com a Europa. O modelo dona de casa passou a ser rechaçado, a tecnologia resolveria os problemas das mulheres. Cosse analisa o papel das revistas de vanguarda para jovens liberadas, o plano modernizador $e$ a influência feminista; tudo isso em contraste com as tímidas mudanças na classe média mais ampla e com o embate ideológico travado por revistas conservadoras (Para Ti) e populares (Vosotras), que tiveram de atender às novas demandas, apropriando-se dos novos códigos sociais, mas sem questionar gênero - reforçavam os lugares tradicionais das mulheres.

Um dos últimos capítulos, de Rebekah Pite, questiona as tarefas domésticas das mulheres argentinas difundidas pelos livros do ícone da cozinha, Doña Petrona, no período de 1970 a 1983. 
Segundo Pite, além de receitas, a chefe ensinava também qual seria o lugar das mulheres na sociedade argentina: perfeitas donas de casa, que sabiam economizar e receber convidados. A autora mostra que a cozinha era um lugar "natural" e seguro para as mulheres, e que o programa de Doña Petrona na televisão foi talvez o único a não sofrer os cortes da censura. Em cima da mesa, uma placa avisava aos convidados: "Proibido falar de política". A apresentadora estava de acordo com os preceitos da ditadura: as mulheres deviam permanecer nos seus lares, mantendo os papéis tradicionais de gênero; era preciso modernizar a tradição, não romper com ela.

O único capítulo do livro que de certo modo destoa de um rigor metodológico é intitulado "Rastros de la ausencia: sobre la desaparición en la obra de Claudia Contreras". María Laura Rosa questiona como a arte pode falar de genocídio e, como resposta, discorre sobre o contexto argentino, fazendo um paralelo com a arte lá produzida, buscando explorá-la como política. "Como falar de um passado que se prolonga no presente?", pergunta a autora. Aos leitores e leitoras ficam algumas impressões que parecem pessoais e uma análise quase emotiva, que não problematiza o uso da arte como fonte para a historiografia. Essa é a ausência que podemos reivindicar.

Com esse apanhado de capítulos, percebemos a amplitude e o aprofundamento de temáticas que trazem para a discussão historiográfica sobre a última ditadura militar argentina a perspectiva das relações de gênero, no âmbito da esquerda política, mas também da direita. De minifaldas, militancias y revoluciones é uma parte importante de um debate, travado em sua transnacionalidade $e^{2}$ por pesquisadoras/es que se preocupam

2 Essas questões são trabalhadas no Brasil por pesquisadoras/es do chamado Projeto Cone Sul, do Laboratório de Estudos de Gênero e História na Universidade Federal de Santa Catarina, que acabaram de editar o livro Resistências, Gênero e Feminismos contra as ditaduras no Cone Sul (Pedro, Wolff, Veiga, 2011), com estudos realizados nos países situados nesse espaço geopolítico, também sob a perspectiva do gênero. Antes dele, uma primeira 
Minissaias, militâncias, revoluções e gênero...

em complexificar a escrita da história, nela inserindo atores/as sociais que não estiveram presentes no que contemplou a historiografia tradicional, mas que trazem histórias e heranças próprias de um período intenso, vivido, lembrado e relembrado por grupos sociais que naquele momento ainda buscavam marcar seus lugares e espaços. Esse livro e as reflexões que ele suscita são marcas materiais de uma legitimidade e, ao mesmo tempo, espaços ocupados por sujeitos históricos ainda em permanente elaboração. Aos estudiosos e interessados, vale a pena conhecer um trabalho de competência acadêmica, que oferece novas possibilidades à historiografia latino-americana, partindo da perspectiva argentina.

\section{Referências bibliográficas}

ANDÚJAR, Andrea et alii. Historia, género y política en los '70. Buenos Aires, Feminaria, 2005. Disponível em www.feminaria.ar.

PEDRO, Joana Maria; WolfF, Cristina Scheibe; VeIGA, Ana Maria. (orgs.) Resistências, Gênero e Feminismos contra as ditaduras no Cone Sul. Florianópolis, Ed. Mulheres, 2011.

PEDRO, Joana Maria; WolfF, Cristina Scheibe, (orgs.) Gênero, Feminismos e Ditaduras no Cone Sul. Florianópolis, Ed. Mulheres, 2010.

compilação de textos elaborados a partir do colóquio "Gênero, Feminismos e Ditaduras no Cone Sul" (realizado na UFSC em maio de 2009) também foi publicada, reunindo autoras/es da Argentina, Uruguai, Chile, Paraguai, Bolívia e Brasil, que problematizam os períodos de ditaduras militares em seus países, imbricados às relações de gênero que os permearam (Pedro e Wolff, 2010). Ligado à Universidade de Campinas, um grupo coordenado pela socióloga Maria Lygia Quartim de Moraes também tematiza as ditaduras militares e as relações de gênero nesse período. Ainda sobre ditaduras, encontramos o trabalho da equipe de pesquisa de Carlos Fico, na Universidade Federal do Rio de Janeiro. 